\title{
Augustyn Ciesielski
}

Nadzwyczajny szafarz sakramentu bierzmowania i konsekracji kościoła w archidiecezji gnieźnieńskiej i warszawskiej

Prawo Kanoniczne : kwartalnik prawno-historyczny 5/3-4, 285-294

1962

Artykuł został zdigitalizowany i opracowany do udostępnienia w internecie przez Muzeum Historii Polski w ramach prac podejmowanych na rzecz zapewnienia otwartego, powszechnego i trwałego dostępu do polskiego dorobku naukowego i kulturalnego. Artykuł jest umieszczony w kolekcji cyfrowej bazhum.muzhp.pl, gromadzącej zawartość polskich czasopism humanistycznych i społecznych.

Tekst jest udostępniony do wykorzystania w ramach dozwolonego użytku. 


\title{
NADZWYCZAJNY SZAFARZ SAKRAMENTU BIERZMOWANIA I KONSEKRACJI KOSCIOEÓW W ARCHIDIECEZJI GNIEZNIENSKIEJ I WARSZAWSKIEJ
}

\begin{abstract}
Świadomość, że Apostołowie udzielali bierzmowania sprawila, ¿e w Kościele Zachodnim sakrament ten sprawowali biskupi. Kośció! Wschodni, w którym od $V$ wieku kapłani powszechnie sprawowali sazrament bierzmowania zarzuca Kościolowi Zachodniemu, że ogranicza administrację bierzmowania wyłącznie biskupom. W wyjątkowych wypadkach św. Grzegorz W. ${ }^{1}$ pozwolił kaplanom Sardynii sprawować sakrament bierzmowania, Mikołaj IV misjonarzom franciszkańskim, Innocenty VIII opatom cysterskim ${ }^{2}$ i innym. Klemens VI (1342-52) uzasadnial Armeńczykom, że szafarzem bierzmowania jest biskup a kaplan wówczas tylko, gdy mu na to pozwoli papież, który ma pełnię władzy. Sobór Florencki r. 1439 określił, że zwyczajnym szafarzem bierzmowania jest biskup a w wypadkach i okolicznościach wyjątkowych papież może tej władzy udzielić kapłanom ${ }^{3}$. Tę definicję ogłosił Sobór Trydencki za dogmatyczną precyzując, że zwyczajnym szafarzem jest biskup nie wykluczając jednak możliwości, że nadzwyczajnym może być kapłan ${ }^{4}$. Po Soborze Trydenckim Stolica Święta raczej przywileju bierzmowania kapłanom nie udzielała. Stopniowo jednak Kongregacje pozwalać zaczęly na terytoriach misyjnych bierzmować kapłanom piastującym godności kościelne bądź dla odznaczenia ich lub wyróżnienia miejsc ${ }^{5}$. Później Stolica Święta uđaielać zaczęla biskupom wladzy subdelegowania kapłanów do bierzmowania, aż wreszcie
\end{abstract}

1 M igne, PL 77, 672. Sw. Grzegorz W. zgodził się, aby kapłani w Sardyni sprawowali sakrament bierzmowania, gdy uprzedni jego zakaz z r. 595 wywolal zgorszenie.

2 P a 11 otini S., Collectio omnium conclusionum et resolutionum quae in causis apud $S$. Congregationem S. Concilii Trident. interpretum, Romae 1892, T XVI, 30.

3 Codicis Iuris Canonici Fontes, cura E. Petri Gasparri editi, 9 vol. Romae 1923-1939, I, 52.

4 D'Abreau Seb., Institutio Parochi, Venetiis 1744, lib. IX, sect. II, 439.

5 Dworecki R., Szafarz sakramentu bierzmowania $w$ Kościele Zachodnim, Studium historyczno-prawne, Lublin 1960, 85. Praca doktorska w maszynopisie. Autorowi za użyczenie do przeglądnięcia składam podziękowanie. 
dekretem „Spiritus Sancti munera” z 14.IX.1946 udzielona została kapłanom pracującym $w$ duszpasterstwie władza bierzmowania wiernych znajdujących się $\mathrm{z}$ powodu ciężkiej choroby $\mathrm{w}$ niebezpieczeństwie śmierci, której jak się przewiduje nie unikną ${ }^{\mathbf{6}}$.

W Polsce do końca XVIII w. sakramentu bierzmowania udzielali wyłącznie biskupi, zresztą, w niektórych okresach bardzo rzadko, jaik wskazują akta wizytacji biskupich. Akta Archidiecezji Gnieźnieńskiej przechowały dwa przywileje uzyskane przez arcybiskupów gnieźnieńskihc, mocą których Stolica Apostolska zezwoliła udzielać sakrament bierzmowania niebiskupom. A mianowicie; Michal Jerzy Poniatowski i jego następca Ignacy Raczyński wyjednali dla archidiecezji gnieźnieńskiej przywilej rzadki w Polsce. Stolica Swięta zezwoliła administrować sakrament bierzmowania zrazu opatom a następnie rozciągnęła go również na innych kapłanów in dignitate constitutis. Indulty te $\mathrm{z}$ punktu widzenia prawa kanonicznego $\mathrm{w}$ Polsce są niezwyklym wyjątkiem.

Prymas Michał Jerzy ks. Poniatowski rozwijał szeroką działalność na polu oświaty, higieny, kultury i zagadnień społecznych zgodnie $z$ duchem epoki Oświecenia, w której żył. Znając problematykę swego czasu, umiał dostrzec zanikanie odporności wobec rozszerzającej się niewiary i obojętności religijnej. Stwierdził też, że wierni, nie będąc umocnieni mocą Bożą ex opere operato sakramentem bierzmowania (umocnienia), który był wówczas rzadko administrowany, byli podatni na wpływy silnego pođówczas inđelérentyzmu religijnego. Aby temu zaradzić, uodpornić i umocnić katolików swej archidiecezji we wierze, - arcybiskup Poniatowski uzyskał lu papieża Piusa VI rzadki na owe czasy przywilej, aby $w$ jego archidiecezji sakramentu bierzmowania udzielać mogli opaci zakonni: Kanoników Regularnych w Trzemesznie, Premonstratensów w Witowie, Benedyktynów w Mogilnie i Cystersów w Lądzie?

W prośbie o udzielenie tego indultu ${ }^{8}$, datowanej $22.12 .1790 \mathrm{r}$. a skierowanej do S. Congr. Concilii, pisal prymas Poniatowski między innymi, że Chrystus ustanowił sakrament bierzmowania, aby odrodzonych sakramentem Chrztu św. wcielić do armii Chrystusowej, aby ich umocnić do wyznawania wiary i mężnego stawania $w$ jej obronie. Należy dać możność, pisal prymas w liście do papieża, korzystania z tego skutecznego środka Łaski, zwłaszcza w czasach, gdy niewiara rozszerzyła się do tego stopnia, że tylko pomoc Boża mogła być najskuteczniejszym

- Acta Apostolicae Sedis 38 (1946), 350. - Komunikat niniejszy ma dorzucić kilka szczegółów wykrytych w Archiwum Archidiecezjalnym w Gnieźnie o nadzwyczajnym szafarzu bierzmowania $z$ terenu Polski.

7 A (rchiwum) A(rchidiecezjalne) G(nieźnieńskie) rkps D 3, s. 621.

8 A A G rkps D 3, s. 620. 
środkiem jej poskromienia i zmniejszenia. A że diecezja arcybiskupa gnieźnieńskiego rozciąga się „,na 50 mil wzdłuż i 30 wszerz”, obejmując 800 parafii, więc $w$ tej sytuacji zaledwie czwarta część wiernych naznaczona była charakterem Sakramentu. Dwu biskupów - sufraganów nie byłoby $w$ stanie podołać wszystkiemu, zwłaszcza przy ówczesnych trudnościach komunikacyjnych. Prymas $w$ omawianym liście podał, że administrowanie sakramentu bierzmowania zajęłoby biskupom cały ich czas, tak że nie byliby w stanie poza tym sprawować żadnych innych obowiązków, a nawet w ciągu 3 lat nieprzerwanej pracy nie byliby w stanie udzielić wszystkim potrzebującym tego sakramentu. Aby więc wiernych nie pozbawic bierzmowania oraz lask i pomocy Bożej, jakie z niego płyną - dla braku szafarza tego sakramentu prosil arcybiskup Poniatowski o wystawienie wymienionego przywileju.

Papież Pius VI indultem $z$ dnia 16 listopada 1790 roku przekazał władzę administrowania sakrementu bierzmowania czterem oznaczonym opatom klasztornym na okres dziesięcioletni. W przywileju tym papież zaznacza, że aczkolwiek nie chce działać przeciwko dyscyplinie krościelnej i prawu kanonicznemu, atoli zaistniały okoliczności takie, że ze słusznych powodów deleguje opatów do sprawowania Sakramentu bierzmowania, powołując się na św. Grzegorza, za którego znana była nodobna praktyka kościelna i który udzialał analogicznych uprawnień.

Indult rzymski wpisany jest do akt Kancelarii Prymasowskiej pod datą 31 stycznia 1791: „Ingrossatio Brevis Ap-lici, quo conceditur faculta quatuor abbatibus videlicet Tremesten., Vitovien., Mogilnen., Landensi conferendum Sacramenti Confirmationis in Archidioecesi Gnesnen. ad decenium" 9 .

Przeglądając księgi konsystorskie gnieźnieńskie, a zwłaszcza wizytacje parafii, spotyka się częściej wzmiankę, że wierni przyjmowali $\mathrm{w}$ parafiach bierzmowanie. Szkoda, że nie wymieniają przez kogo był udzielany. Antoni Raczyński ${ }^{10}$, opat cystersów z Lądu, któremu prymas udzielił licencji na pontyfikalne celebrowanie Mszy sw. i innych nabożeństw $w$ archidiecezji gnieźnieńskiej ${ }^{11}$, tak jak je opaci we własnych kościolach klasztornych odprawiać mogą, w myśl przywileju rzym-

9 A A G rkps G II, n. 2.

10 Raczyński Bartlomiej Antoni, ochrzczony 8.VIII.1756, habit cystersów w Lądzie przyjąl 30.VII.1781, teologię studiował na Studium Generale w Mogile, kapłaństwo otrzymał w Krakowie dnia 10.VII.1786, wybrany na opata Lądu 22.X.1791, biskupem-sufraganem gnieźnieńskim zostal 27.III.1809, konsekrowany 20.VIII.1809 r., zmar1 16.III.1821. AAG, rkps D 7, 128, 146, 162; rkps D 7, 287; WAP Poznań, Ląd B 3; Bledzew C 40, C 9; Archiwum Diec. Włocławek, rkps 174 i rkps 313; AAG rkps D 7, 287. Biblioteka Sem. Duchownego w Pelpinie, rkps 310.

11 A A G, rkps D 7, 263; D 4, 352. 
skiego uzyskał dnia 6.2.1792 r. w kancelarii warszawskiej prymasa zlecenie do udzielania sakramentu bierzmowania ${ }^{\mathbf{1 2}}$.

Podobną delegację na udzielanie bierzmowania otrzymal ${ }^{13}$ Eustachy Suchecki opat Witowa 26 czerwca 1793 na trzy lata ${ }^{14}$.

Akta archidiecezji gnieźnieńskiej i Archiwum Akt Dawnych diecezji we Włoclawku ${ }^{15}$ pouczają, że opat Raczyński z przywileju bierzmowania korzystal i sakramentu udzielał bardzo często nie tylko wiernym sąsiednich parafii, którzy przybywali do jego opactwa w Lądzie, ale również w różnych kościołach archidiecezji gnieźnieńskiej ${ }^{10}$.

Antoni Raczyński opat Lądu niebawem zostaje sam biskupem Hetalońskim, sufraganem gnieźnieńskim ${ }^{17}$, zatrzymując urząd opata Lądu, którą to godność rząd pruski pozostawił mu dożywotnie. W tym bowiem czasie godność opatów klasztornych, którzy mieli udzielać sakramentu bierzmowania, zaczęla wakować na skutek zarządzeń rządu pruskiego, zmierzającego do kasaty zakonów przez przejęcie majątków opackich na skarb państwa. Minęło dziesięciolecie, w czasie którego opaci udzielali bierzmowania w archidiecezji gnieźnieńskiej. Następca prymasa Poniatowskiego arcybiskup Ignacy Raczyński, sędziwy wiekiem, administrował również diecezją warszawską. Zwrócił się do Stolicy Apostolskiej, aby pozwoliła opatom udzielać sakramentu bierzmowania. Nie przechowała się prośba prymasa wniesiona do Rzymu. Mamy natomiast indult Piusa VII, udzielony na udiencji 4 czerwca 1809 roku na wniosek Kongregacji de Propaganda Fide. Mocą udzielonego przywileju prymas Ignacy Raczyński może subdelegować nie tylko trzech dowolnych, imiennie nie oznaczonych opatów, ale nawet trzech kapłanów diecezjalnych lub zakonnych jakiegokolwiek instytutu życia wspólnego, by mogli udzielać bierzmowania na terenie archidiecezji gnieźnieńskiej i warszawskiej, ale wyłącznie i tylko w czasie trwania misji. Udzielający bierzmowania ma się stosować do instrukcji wydanej przez Kongregacje de Provaganda Fide dnia 4 maja 1774 dla terenów misyjnych. Szafarz udzielający bierzmowania nie ma prawa na mocy tego indultu do używa-

12 A A G, rkps D 4, 352; G VI, nr 2.

13 A A G, rkps D 5, 94. Uprzednio otrzymal licencje na pontyfikalne celebrowanie $\mathrm{w}$ archidiecezji; - D 3, 620 .

14 Opat $\mathrm{w}$ Mogilnie został biskupem Martynopolitańskim i sufraganem gnieźnieńskim. - A A G, rkps D 4, 215.

15 Archiwum Akt Dawnych Diecezji Włocławskiej, rkps Ląd 313 Series Confirmatorum Antoniego Raczyńskiego opata lądzkiego a później sufragana gnieźnieńskiego, jak również święceń kapłańskich, których udzielal w czasie od 1792-1809 r. Wymieniony opat udzielał bierzmowania zanim zostal biskupem. Liczba bierzmowanych wynosi 36866 .

16 A A $G \operatorname{rkps}$ E 33, E 32.

17 A A G rkps D 7, 146, 162. 
nia pontyfikaliów, chyba że ten przywilej oddzielnie i osobiście posiada. Indult, jaki otrzymał prymas Raczyński, ma charakter specjalnej laski i nie może stanowić precedensu na przyszłość, któryby wprowadzal prawny zwyczaj. Czas trwania przywileju obejmowal lat dziesięć ${ }^{18}$.

Porównując ten przywilej $z$ uprzed nim, uzyskanym przez prymasa Poniatowskiego, budzi się pytanie, dlaczego papież posłużył się Kongregacją de Propaganda Fide, a nie tak, jak uprzednio udzielił bezpośrednio. $\mathrm{Z}$ indultu wynika, że może raczej prymas Raczyński zwrócił się do Kongregacji de Propaganda Fide, dlatego że posiada obszerniejsze i liczniejsze przywileje dla krajów misyjnych, a on zamierzał w archidiecezji guieźnieńskiej i diecezji warszawskiej przeprowadzać misje. Zamiar odnowienia diecezji przy pomocy misji stał się powodem i tytułem, że skierował się do Kongregacji misyjnej i poprosił, by ta pozwoliła korzystać, względnie rozciągnęła przywileje, jakie posiada na kraje misyjne odnośnie udzielania bierzmowania. Indult udzielony prymasowi Raczyńskiemu jest rzeczowo ścieśniony i węższy niż indult uzyskany przez jego poprzednika Poniatowskiego. Pod tym jednak względem jest szerszy, że on nie ogranicza subdelegacji na trzech opatów, ale pozwala szafować bierzmowanie kapłanom innym poza terenem misyjnym $w$ diecezjach, które nie podpadają pod jurysdykcję Kongregacji de Propaganda Fide. Mimo wszystko Stolica Apostolska okazala wyjątkową życzliwość arcybiskupowi i zaznacza, że ta łaska nie powinna wprowadzać precedensu prawnego. Uzyskany indult wszedł w życie. Żródła bowiem historyczne archidiecezji i diecezji warszawskiej ${ }^{10}$ podają, że Wojciech Kamieński, opat witowski, otrzymał upoważnienie do bierzmowania $w$ stroju pontyfikalnym w czasie misji $\mathbf{2 0}$. Analogiczne uprawnienie otrzymał dnia 31.VIII.1809 kanonik gnieźnieński, infulat-prepozyt kamieński, IMarcin Szmitt ${ }^{21}$. Miesiąc wcześniej 25.VII.1809 otrzymał on ogólną licencję na odprawianie pontyfikalnych celebr na terenie całej archiđiecezji $\mathbf{2 2}$.

18 A A G rkps D 7, 262; D 10, 70.

19 Archiwum Archidiecezji Warszawskiej zaginęło doszczętnie, natomiast Archiwum Archidiecezjalne w Gnieźnie nie posiada najważniejszych ksiąg obemujących biskupie czynności prymasów, ale tylko przechowało księgi oficjalskie Archidiakonatu gnieźnieńskiego. Omawiane przywileje znajdują się $w$ tzw. Aktach Postcurialia Sign. D $1-10$ z. czasów prymasów Poniatowskiego i Raczyńskiego. Z wcześniejszych czasów jedynie do pontyfikatu Zbigniewa Oleśnickiego istnieje rkps A 58. umieszczony $w$ ksiegach oficjalskich.

20 A A G, rkps D 7, 279

21 A A G, rkps D 7, 294

22 A A G, rkps D 7, 274. Prepozyci kamieńscy na mocy bulli z roku 1656 mieli przywilej używania pontyfikaliów, mitry i pastorału.

19 - Prawo Kanoniczne $\mathrm{Nr} 3-4$ 
Drugi niezwykły w Polsce przywilej uzyskali prymasi polscy dla archidiecezji gnieźnieńskiej i administrowanej warszawskiej, że mogli delegować wyłącznie opatów do konsekracji ołtarzy, kościołów i benedykcji dzwonów.

Wykonywana przez opatów benedykcja dzwonów, konsekracja kielichów i paten, portatylów i ołtarzy stałych nie byia, ani za granicą ani w Polsce czymś niezwylklym. Albowiem na mocy bulli Innocentego VIII „Exposcit" z dnia 9 lipca $1489^{24}$, zrazu dla pięciu pierwszych opatów cysterskich, potem na wszystkich opatów tegoż zakonu rozszerzonej, wymienione konsekracje niebiskupi wykonywali również w Polsce. Hieronim Rozdrażewski biskup włocławski, dziwi się przy wizytacji klasztoru Cystersów w Koron'owie, że w kościele tamtejszym znajdują się oltarze niekonsekrowane, które przecież opat mógł konsekrować. Polecił współczesnemu opatowi Wawrzyńcowi Żalińskiemu dokonać konsekracji portatyli i ołtarzy na mocy wladzy, jaką posiadają opaci, „cum pontificalium exercendorum potestatem habeant ${ }^{24}$. Sprawozdanie $z$ tej wizytacji wysłał również do Rzymu w roku 1594. Opaci konsekrowali ołtarze również $w$ innych kościołach swojego zakonu ${ }^{25}$. Na własnym terytorium opaci mogli dokonywać konsekracji kielichów, portaty!i i dzwonów również dla innych kościolów zakonnych czy diecezjalnych $o$ ile ich o to rektorzy kościołów prosili i te przedmioty im do konsekracji przyniesiono ${ }^{26}$. Natomiast na terenie obcym wykonywać mogli na zlecenie lub cum licentia ordynariuszy miejscowych. Po restrykcji wydanej przez S. C. Rituum dnia 27 września 1659 r. ograniczającej usus pontificalium infułatów niższych od biskupa taż Kongregacja 17 czerwca 1660 oświadczyła: ,abbates cistercienses tamquam privilegiis specialibus ab Apostolica Sede condecoratos, quibus S. C. derogare numquam suis decretis intendit, non comprehendi in decreto generail emanato" 27 . Faktycznie i w tym okresie opaci wykonywali równiez wy mienione konsekracje w Polsce. Swiadczą o tym akta wizytacji kościołów, których wizytatorowie od biskupa delegowani wyszczególniają konsekracje portytylów dokonanych przez opatów, np. w r. 1694 konsekrował portatyle Ignacy Bernard Gniński ${ }^{28}$ opat koronowski. Podobnie było $w$ innych krajach Europy. Benedykt XIV $w$ brewe „In Suprema" 7 dnia 10 czerwca 1741 r. ... ex certa scientia et de plenitudine Apostolicae potestatis" umocnif opatów cysterskich w wykonywaniu omawianych przywilejów. Brewe to znajduje się w kolekcji auten-

23 Caeremoniale abbatum, Westmalle 1939: Diplomata.

24 Monumenta Historica Dioecesis Vladislaviensis, VII, 49.

25 Stams (Austria) rkps H, 18, 23;- Bibl. Sem. Pelplin rkps 422, 219.

26 Tamże H, XVIII, 14.

27 Caeremoniale abbatum, tamże 6 .

28 A A $G$ rkps $G 55$ b, 12 
tycznej dekretów S. C. Rituum nr. 2333 (wydanej Romae: 1898 T. II) i znajduje się wśród źródel Kodeksu Prawa Kanonicznego pod kan. $1147 \mathrm{w}$ uwadze 3: Brixinen: 31 aug. $1737^{29}$. Przywileje dotyczące konsekracji dzwonów, ołtarzy i kielichów pozostały do dzisiaj w mocy i w myśl kan. 1147 dla tych, którzy posiadaja inđult apostoisłki. W świetle reskryptu S. C. de Religiosis $\mathrm{z}$ dnia $6 \mathrm{kwietnia} 1914$ nawet altare fixum mogą konsekrować opaci cystersów i trapistów supposita licentia ordinarii na jakimkolwiek terenie ${ }^{30}$.

Natomiast niespotykanym jest dotychczas w Polsce przywilej konsekracji kościołów przez niebiskupów. Uzyskał go prymas Ignacy Raczyński 15 lipca 1809 roku dla archidiecezji gnieźnieńskiej i warszawskiej ${ }^{31}$. S. Congregatio Rituum za specjalną aprobatą Ojca św. nadała prymasowi polskiemu indult ,... deputandi tres abbates Mogilnensem, Vitoviensem, Landensem pro benedictione campanarum, pro reconciliatione ecclesiarum pollutarum et etiam pro earundem ecclesiarum consecratione praedictis duabus dioecesibus". Prymas Ignacy Raczyński na mocy przywileju delegowal opatów z Mogilna i Witowa do konsekracji kościołów na przeciąg dwóch lat. Akta przekazały taką delegację udzieloną opatowi $\mathrm{z}$ Witowa Kamińskiemu 12 stycznia $1810 \mathrm{r} \cdot{ }^{32}$. Opat Lądu Antoni Raczyński już był̇ biskupem. Na ogół bardzo rzadko udzielała poza terenami misyjnymi Stolica Apostolska wiadzy do konsekrowania kościolów niebiskupom ${ }^{33}$.

Te dwa rzadkie indulty $w$ Polsce: kierzmowania i konsekracji kościołów, jakie mogli wykonywać niebiskupi, z czasu pontyfikatu prymasów Polski Poniatowskiego i Raczyńskiego świadczą między innymi o specjalnych względach, jakimi wówczas cieszyli się u Stolicy Apostolskiej arcybiskupi gnieźnieńscy, skoro ich takimi obdarzyła przywilejami, które stanowią mały przyczynek do historii prawa kanonicznego w Polsce.

\section{Privilegia}

I

Venerabili Fratri Michaeli Archi-Episcopo Gnesnensi ${ }^{34}=$ Intus Pius Papa VI $=$ Venerabilis Frater salutem et Apostolicam Benedictionem.

29 Bullarium Romanum, edit. Prati 1845 (Benedicti XIV... Bullar.

T. I, str. 74-77).

30 Caeremoniale abbatum 44.

31 A A G, rkps D 10,71-72.

32 A A G, rkps D 7, 341 .

33 Stams, rkps H. XVIII, 15. Biskup z Brixen na mocy facultas Romana polecił opatowi Augustynowi ze Stams konsekrować kościơ $\mathrm{w}$ Send 11.VII.1716 $\mathrm{r}$.

${ }^{34}$ A A G rkps D 3,621; - G 11 n. 2. 
Etsi ab eo tempore in quo ad Apostolici Ministerii Officium nullis Nostris suffragantibus meritis, sed ex divinae bonitatis abundantia vocati fuimus quantum in Nobis fuit, nihil contra Ecclesiae Disciplinae regulas, ac sacrorum Canonum dispositionem fieri passi simus atque hortando, suadendo, terrendo illius violatoribus Deo adiuvante obsistere conati sumus, nihilominus cum quaedam sint, quae nulla possunt ratione convelli, ita multa sint, quae pro rerum necessitate temperari possunt. Nos pro ea Paterna charitate, qua omnes omnino Christi Fideles in Domino complectimur, in iis, quae specialem eorundem Christi Fidelium profectum concernunt, Aplicam Auctoritatem Nostram interponere iustis ac rationabilibus concurrentibus causis quo ad integrum Nobis fuit haud detrectavimus, prout in Domino salubriter expedire arbitrati sumus. Exponi siquidem Nobis nuper fecisti quod tum ob tuae Gnesnensis Dioecesis amplitudinem, atque immensitatem, nisi dificillime ad singula tuae Dioecesis huiusmodi loca, pro Sacramento Confirmationis administrando personaliter $T e$ conferre valeas, quo autem animarum Christi Fidelium quae tuae curae commissae reperiuntur saluti consultum sit, quatuor Abbates in tua Dioecesi existentes, nempe Tremesnensem Canonicorum Regularium Congregationis Lateranensis Ordinis Sancti Augustini, Vitoviensem Canonicorum Regularium Ordinis Praemonstratensis, Mogilnensem Monachorum Ordinis Sancti Benedicti et Landensem IMonachorum Ordinis Cisterciensis, qui Sacramentum huiusmodi loco et vice tua eis conferre valeat, deputare posse, summopere cupiat. Nos cum Delegatio simplicis Sacerdotis, qui ubi Episcopis ob locorum distantiam impossibile, vel difficile admodum sit, populorum necessitatibus praesentes fieri Sacramentum conferre possit, neque nova sit, neque inusitata cum Sancti Gregorii Magni, aliorumque Romanorum Pontificum Praedecessorum Nostrorum sanctissimis innitatur exemplis, Spirituali Dominici Gregis tuae Pastorali sollicitudini commissi necessitati providere. Teque specialibus favoribus et gratiis prosequi volentes, et a quibusvis excommunicationis et interdicti, aliisque Ecclesiasticis sententiis, censuris, et paenis, a iure, vel ab homine, quavis occasione vel causa latis, si quibus quomodo libeti innodatus existis, ad effectum praesentium duntaxat consequendum harum serie absolventes fore censentes, supplicationibus tuo Nomine Nobis super hoc humiliter porrectis inclinati, Fraternitati Tuae memoratos quatuor Abbates Tremesnensem scilicet, Vitoviensem, Mogilnensem et Landensem ad decennium proxime futurum Christi Fidelibus locorum Dioecesis tuae huiusmodi, ad quae personaliter conferre non poteris ut praefertur, dictum Confirmationis Sacramentum oleo tamen et Chrismate, per Te seu per quemcunque Catholicum Antistitem gratiam et Communionem Sae Sedis Aplicae habentem benedictis, servatisque alias servandis administrare libere ac licite possint. Authoritate Nostra Apostolica constituendi et deputandi facultatem 
pari Authoritate tenore praesentium concedimus et impertimur non obstantibus Apostolicis, ac in Universalibus Provincialibusque et Synodalibus Conciliis editis generalibus vel specialibus constitutionibus et Ordinationibus caeterisque contrariis quibuscunque. Datum Romae apud S. Mariam Maiorem sub Annulo Piscatoris die XVI Novembris IVDCCXC Pontificatus Nostri Anno Decimo Sexto $=R$. Cordis Braschius de Honestis.

\section{II}

Facultas Apostolica subdelegandi tribus Abbatibus Claustralibus Archidioecesis Gnesnen et Dioecesis Varsavien Sacramentum Confirmationis. ${ }^{35}$

Ex Audientia Sanctissimi habita die 4 Junii 1809, Relatis per Me infrascriptum S. Congregationis de Propaganda Fide Secretarium precibus R. P. D. Ignatii Raczyński moderni Archiepiscopi Gnesnen, et Administratoris Dioecesis Varsavien, quibus Sacras Missiones in Locis dictarum Dioecesium indicere cupiens, humiliter supplicabat, ut facultas sibi tribueretur: subdelegandi tribus Abbatibus Claustralibus potestatem administrandi Fidelibus dictarum Dioecesium Sacramentum Confirmationis; SS-mus Dominus Noster Pius Divina Providentia P. P. VII. pium Laudati Archiepiscopi desiderium summopere commendans, ex Gratia speciali in exemplum non protrahenda, Eidem benigne indulsit, ut tres Abbates proefatos, seu tres alios sibi benevisos Presbyteros Saeculares, vel cujusvis Ordinis, Congregationis, aut Instituti Regulares subdelegare possit, qui in dictis Missionum Locis, et earumdem Missionum tempore tantum perdurante, Sacramentum Confirmationis Christi Fidelibus dictarum Dioecesium administrare valeant, cum oleo tamen ab Episcopo benedicto, et absque Pontificalibus Insignils, etiam quoad eosdem Abbates, quatenus hujusmodi Indulto decorati non reperiantur, ac juxta Instructionem editam jussu $\mathbf{S}$. Congregationis de Propaganda Fide die 4 Maii $1774=$ Datum Romae ex Aedibus dictae S. Congregàtionis Die et Anno, quibus supra. Gratis sine ulla omnino Solutione quocumque titulo - L. S. J. B. Quarantotti Secr. Applic.

Sacra Rituum Congregatio, de speciali Apostolica Authoritate delegata supplicanti hodierno Archi-Episcopo Gnesnen Administratori Ecclesiae Varsavien. inspectis is quae in supplici Libello emanantur, ex peculiari gratia, potestatem fecit ad biennium deputandi infrascriptos tres Abba-

${ }^{35}$ A A G rkps D 7, 262; - D 10, 70. 
tes scilicet Mogilnensem Ordinis S. Benedicti, Vitoviensem Ordinis Praemostratensis, et Landensem Ordinis Cisterciensis pro benedictione campanarum, pro reconciliatione Ecclesiarum pollutarum et etiam pro earundem Ecclesiarum consecratione in praedictis duabus Dioecesibus: quibuscumque in contrarium disponentibus minime obstantibus. Die 15 Julii 1809. L: S: Michael Cardinalis de Petro Apostolicus Delegatus. Idem Caprineo S. R. C. Secr. ${ }^{36}$

O. Augustyn Ciesielski

36 A A G rkps D 10, 72. Powyższe trzy przywileje znajdują się w Kopiarzach rzymskich indultów dla Arcybiskupów Gnieźnieńskich i Administratorów Warszawskich od roku $1807 \mathrm{w}$ Archiwum Archidiecezjalnym w Gnieźnie pod sygnaturą D nr 1-9 obejmującą Acta Postcurialia z lat 1785-1818. Pierwszy z zamieszczonych indultów mieści się również pod sygnaturą G II: Acta Pontificalia $z$ lat 1426-1846. Inne szczególy tego komunikatu zaczerpnięte są z Acta Visitationum działu E nr $1-40$ z lat 1592-1818. Oryginały opublikowanych przywilejów dotychczas nie są znane. 